Atıf İçin: Çelik F, Doğan O, 2021. Güçlendirme Ankrajlarının Kesme Performansının Mevcut Yığma Duvarlar Üzerinde Belirlenmesi. Iğdır Üniversitesi Fen Bilimleri Enstitüsü Dergisi, 11(2): 1230-1242.

To Cite: Çelik F, Doğan O, 2021. Determining The Shear Performance of Strengthening Anchorage on an Existing Clay Block Masonry Wall. Journal of the Institute of Science and Technology, 11(2): 1230-1242.

\title{
Güçlendirme Ankrajlarının Kesme Performansının Mevcut Yığma Duvarlar Üzerinde Belirlenmesi
}

\author{
Fatih ÇELIK ${ }^{1 *}$, Orhan DOĞAN ${ }^{2}$
}

\begin{abstract}
ÖZET: Türkiye nüfusunun büyük bir kesimi deprem riski yüksek bölgelerde yaşamaktadır. Bu bölgelerde bulunan binaların, yapıldıkları yıllardaki mühendislik hizmetlerindeki eksiklik, kalitesiz malzeme kullanımı ve işçilik hatalar nedeniyle mevcut binaların yaklaşık 2/3'ünün güçlendirilmesi gerektirmektedir. Mevcut bir yığgma duvarı yatay yüklere karşı güçlendirmek için duvarın bir ya da iki yüzeyine eklenecek çelik veya betonarme levhaların mevcut duvarla kısmi veya tam bir bağla birlikte hareket edebilmesi için konektörlere ihtiyaç vardır. Mevcut duvarın ve eklenecek güçlendirme elemanının yatay deprem kuvvetlerine karşı rijitlikleri farklı olacağından, aralarında oluşacak kesme ve çekme kuvvetlerine karşı, bu konektörlerin yeterli esneklik, aralık, çap ve derinlikte olması gerekmektedir. Bu çalışmada konektör olarak, esnek ve kolay temin edilebilir olması bakımından betonarme çelik çubuk parçaları tercih edilmiştir. Yığma duvar yüzeyine ankre edilecek bu konektörlerin sayılarını belirleyebilmek için çap ve derinliklerine bağlı kesme performanslarının belirlenmesi büyük önem arz etmektedir. Bu çalışma kapsamında, mevcut bir binanın duvarlarına ankrajlanan farklı çaplarda ve derinliklerde güçlendirme çelik çubuklarının kesme performanslarını belirleyebilmek için özel tasarlanmış, pratik ve kullanışlı çelik levhalı deney düzeneği kullanılmış ve 3 farklı binada toplam 21 adet kesme deneyi yapılmıştır. Ankraj kesme performansı üzerinde ankraj derinliğinin donatı çapına oranla çok fazla etkili olduğu görülmüştür. Ayrıca ankraj çubuğunun çapına ve derinliğine bağlı olarak kesme kuvvetini veren parabolik bir denklem elde edilmiştir.
\end{abstract}

Anahtar Kelimeler: Kil Blok Tuğlalı Duvar, Yığma Bina, Yığma Binalarda Depreme Karşı Güçlendirme, Ankraj Donatılarının Kesme Performansı, Ankraj Kesme Plakası.

\section{Determining The Shear Performance of Strengthening Anchorage on an Existing Clay Block Masonry Wall}

ABSTRACT: A large proportion of Turkey's population live in high-risk earthquake zone. During the years when the buildings were built, apporximately $2 / 3$ of the existing buildings in the earthquake zone need to be strengthened, due to the lack of engineering services, poor quality materials and workmanship errors. In order to strengthen an existing masonry wall against horizontal loads and resist horizontal loads partially or fully with the existing wall, connectors are needed for the steel or reinforced concrete shear wall attachments on one or both surfaces of the wall. Since the rigidities of the existing wall and attached reinforcement elements are different against horizontal earthquake forces, these connectors must have sufficient flexibility, spacing, diameter and depth against the shear and pull-out forces that will occur between these two blocks. In this study, anchoring steel bars are preferred as connectors for being flexible and easily attainable. In order to determine the number of the connectors to be anchored to a masonry wall surface, determination of the shear performances depending on the diameter and the depth of the connectors is of great importance. Within the scope of this study, a new practical shear test plate is designed to determine the shear performance of reinforcement anchors with different diameters anchored on an existing building walls. 21 shear tests were performed on three different existing masonry buildings using the specially designed shear test plate. Although the effect of diameter of the steel rods on the shear capacity of the rods showed negligible effect, anchorage depth of the rods showed a significant effect as the most effective parameter. In addition, a parabolic equation is obtained that gives shear performance of the anchorage depending on its diameter and depth.

Keywords: Clay Block Brick Wall, Masonry Building, Earthquake Reinforcement in Masonry Buildings, Cutting Performance of Anchoring Reinforcement, Anchoring Shear Plate.

\footnotetext{
${ }^{1}$ Fatih ÇELIKK (Orcid ID: 0000-0002-1676-1846), Ankara Büyükşehir Belediye Başkanlığı, Yapı Kontrol Dairesi Başkanlığı, Proje ve Birim Fiyat İnceleme Şube Müdürlüğü, Ankara, Türkiye

${ }^{2}$ Orhan DOĞAN (Orcid ID: 0000-0002-4942-1725), Kırıkkale Üniversitesi, Mühendislik ve Mimarlık Fakültesi, İnşaat Mühendisliği, Kırıkkale, Türkiye

*Sorumlu Yazar/Corresponding Author: Fatih ÇELIKK, e-mail: fatihcelik666@hotmail.com

Bu çalışma Fatih Çelik'in Yüksek Lisans tezinden üretilmiştir.
} 


\section{GİRiş}

Yığma bina, örgü ve sıva harcı ile taş, tuğla, kerpiç bims-blok vb. malzemelerin bir araya gelmesiyle oluşan, taşıyıcısı duvarlar olan bir yapı türüdür (Bayülke, 1992; Akgül ve Doğan, 2020). Betonarme yapıların inşasının hız kazandığı yüzyıl olarak nitelendirilebilecek 2000'li yıllar; yeni yı̆̆ma yapıların inşasını yavaşlatmış olsa da mevcut yığma yapılar üzerinde çok sayıda hasar tespiti ve güçlendirme çalışmalarını da barındırmaktadır (Akgül ve Doğan, 2019). 6306 sayılı kanunla kentsel dönüşüm kapsamında imar eksiği olan ve depremsel açıdan aşırı risk taşıyan binaların yıkılarak yenilenmesi, riskli binalar açısından büyük bir dönüşüm getirmiştir. Ancak imar eksiği olmayan ve yıkılarak yeniden yapılması ekonomik olmayan binaların, geleneksel mantolama veya perde ekleme yöntemleriyle güçlendirilmesi bina kullanıcıları tarafından rahatsız edici ve maliyetli bulunması nedeniyle tercih edilmemektedir (Doğan ve ark., 2020; Akgül ve Doğan, 2020).

Mevcut binaların iç mekân kullanımını engellemeden, dış cephelerinden ankrajlarla bağlı kesme duvarları ve çelik çaprazlar eklemek suretiyle güçlendirilmesi, maliyet, uygulama kolaylı̆̆ ve bina sakinlerince tercih edilir bir yöntem olması bakımından, kentsel dönüşümün akabinde bu tıkanıklığın giderilmesi noktasında büyük önem arz etmektedir.

Mevcut yığma binaların deprem risk analizinde, duvarların kesme performansına ilişkin farklı çalışmalar mevcuttur (Doğan ve ark., 2020; Odacıoğlu, 2018; Çalışkan, 2010; Çalışkan ve ark., 2011; Çelik, 2018; Silveri ve ark., 2016; Doğan ve Odacığlu, 2019; Öztürk, 1997). Ancak eklenecek güçlendirme elemanları ile mevcut duvarlar arasında oluşacak kesme kuvvetlerini karşılayacak bağlayıcı konektörlerin kesme performansının yerinde tespitine ilişkin bir deneysel çalışma bulunamamıştır.

Bu çalışma kapsamında, mevcut yığma duvarların güçlendirilmesi için Şekil 1.'de görüldügü üzere duvar yüzeyine ankrajlanan donatıların çap ve ankraj deriniklerine bağlı olarak kesme performansını belirleyebilmek için kolay taşınabilir ve pratik bir deney plakası tasarlanarak, bir grup deney yapılmıştır.

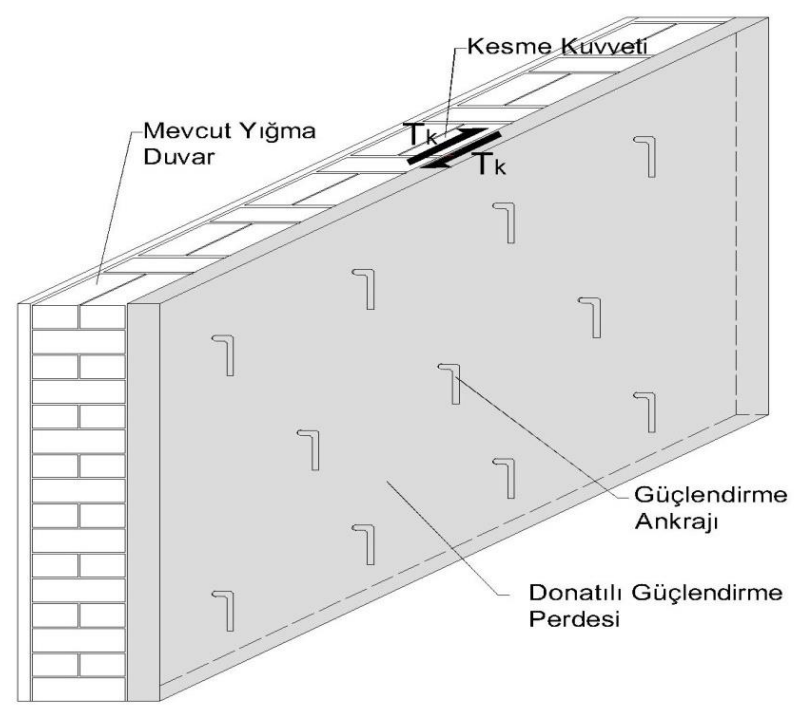

Şekil 1. Mevcut Yığma Duvarda Güçlendirme Perdesi ve Ankrajları.

\section{MATERYAL VE METOT}

\section{Deney Düzeneği}

Duvar yüzeyine ekilen Ø6-16 çapında ankraj donatılarının kesme performanslarının araştırılması için hazırlanan deney düzeneğinde; hidrolik pompa, hidrolik basınçölçer, hidrolik kriko, çelik lama, 
çelik yükleme levhası, ankraj çubukları, komperatör ve diğer destek levhaları belirli bir sıra ile bir araya getirilmiştir (Şekil 2).

Deneyde kullanılan donanım elemanları olarak; özel kesme levhası (St 37), hidrolik kriko, hidrolik yă̆ pompası, analog deplasman ölçer, N-Schmidt test çekici, çelik destek plakaları (St 37), çelik lama (St 37) ve deney numunesi olarak farklı çaplarda ankraj donatı çubukları (BÇIII nervürlü) kullanılmıştır. (Şekil 3).

Hidrolik kriko yardımıyla duvar yüzeyine paralel uygulanan kesme kuvveti altında, duvar yüzeyine ankre edilmiş donatı çubuklarının kesme performanslarını araştırmak amacıyla, yırtılma, ezilme ve burkulma olmayacak şekilde güçlendirilerek özel bir çelik levha tasarlanmıştır.

Deneyde donanım elemanı olarak; alt ortasından 10 ton kapasiteli, tek tesirli (itme özellikli), strok boyu $15 \mathrm{~cm}$, kriko başlık çap $8 \mathrm{~cm}$, başlık etki alanı $50.27 \mathrm{~cm}^{2}$ olan hidrolik kriko ve 0-300 bar hidrolik basınç ölçerli, 10 bar hassasiyetli, patlama basıncı 1800 bar, çalışma basıncı 445 bar, 1.5 m boyunda alüminyum gövdeli hidrolik el pompası, manyetik ayaklı sabitlenebilen, $0.01 \mathrm{~mm}$ hassasiyetli ve $1.5 \mathrm{~cm}$ uzama boyunda bir salgı komparatör kullanılmıştır. Yüklerin uygulanmasında hidrolik kriko altlarında destek ve yükseklik farkını azaltmak ve komparatörü sabitleyebilmek için $2.5 \mathrm{~cm}$ kalınlığında ve 20*30 cm boyutlarında destek plakları ve ayrıca kriko yükünü plakaya doğrudan kesme yükü olarak aktarabilmek için duvar yüzeyine paralel yerleştirilmek üzere $1.0^{*} 1.0 \mathrm{~cm}$ kare kesitli $10 \mathrm{~cm}$ boyunda bir çelik çubuk kullanılmıştır. Deney numunesi olarak $25 \mathrm{~cm}$ boyunda ve Ø10, Ø12 ve Ø16'lık nervürlü ankraj çubukları hazırlanmıştır.

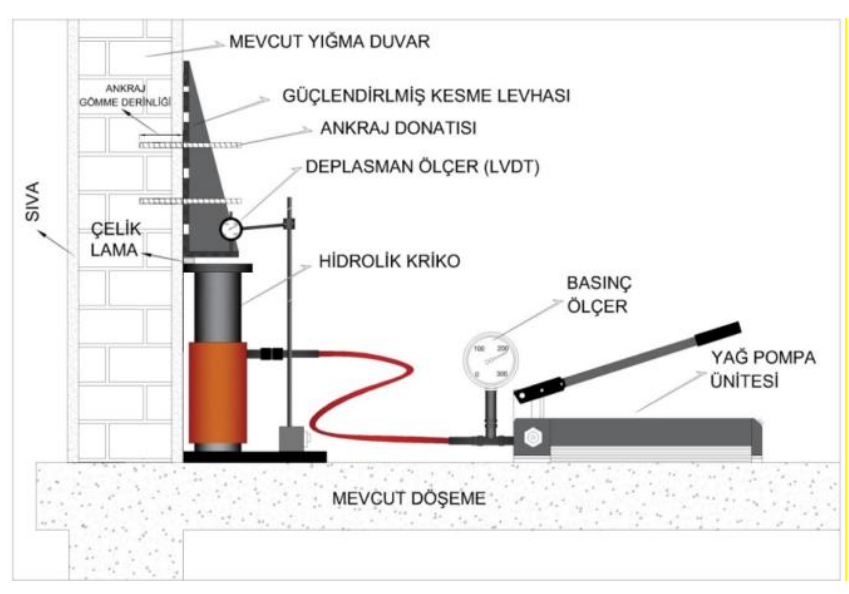

Şekil 2. Duvar Yüzeyine Ankrajlanan Donatıların Kesme Deney Düzeneği

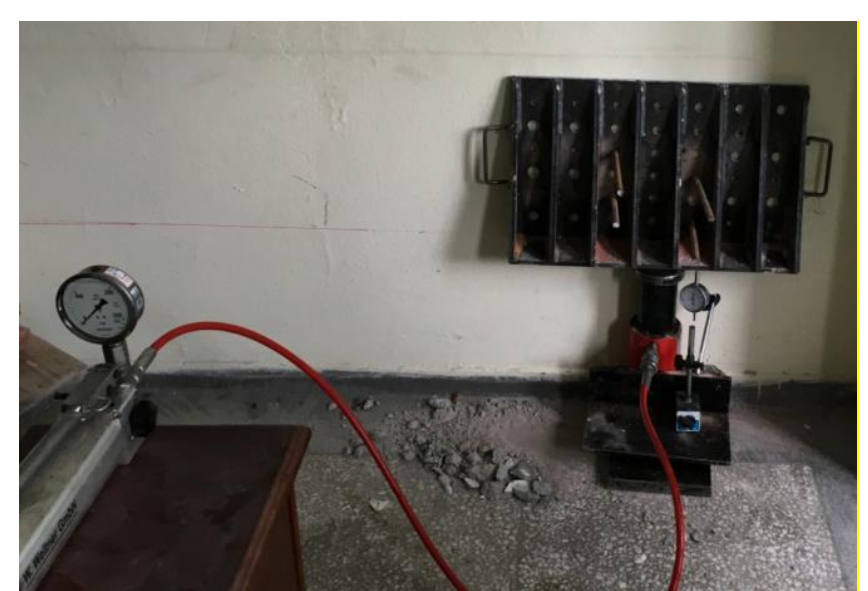

Şekil 3. Ankraj Donatısı Kesme Performansı Deney Düzeneği

Ayrıca örgü malzemelerinin mekanik özellikleri ile ankrajların kesme performansı arasındaki bağıntıyı görebilmek adına tuğlanın, örgü ve sıva harcının ayrı ayrı basınç dayanımlarını test etmek için tahribatsız deney aleti olan N-Schmidt çekici kullanılmış olup, çekicin sekme aralığı (R) 10-100, ölçüm aralığı 10-70 $\mathrm{Nmm}^{-2}$ ve darbe enerjisi 2.207 Nm'dir (TS EN 12504-2, 2014).

\section{Deneyin Yapılışı}

Kesme deneylerine konu olan 3 bina; GMK Bulvarı No:125, Bişkek Caddesi No:44 ve Bahriye Üçok Caddesi No:11'dir ve binalar için çalışma kapsamında sırasıyla B1, B2, B3 kısaltmaları kullanılmıştır.

Kesme levhası duvar yüzeyine yerden yaklaşık $40 \mathrm{~cm}$ yükseklikte tutularak, aynı çapta ve yükleme aksına simetrik olan 4 adet levha deliğinden duvar yüzeyine ankraj delik yerleri işaretlenmiştir. İşaretli yerlere açılan deliklere aynı çapta 4 adet ankraj çubuğu eşit derinlikte çakılmış ve kesme levhası duvar 
yüzeyine ankraj çubuklarına geçirilerek yerleştirilmiştir. Hidrolik kriko, zemin ile birbirine paralel olan kesme levhasının alt yüzeyini ortalayacak şekilde, alt kısmından çelik plaka ile desteklenerek yerleştirilmiştir. Deney düzeneği hazırlandıktan sonra hidrolik kriko yardımıyla kuvvet verilmeye başlanmıştır. Uygulanan kuvvetle birlikte yukarı yönlü hareket eden kesme levhasının ötelenme boyu, zeminde bulunan çelik levhaya sabitlenen komperatör ile yukarı doğru meydana gelecek deplasmanlar ölçülmüsşür. Deney işlemi maksimum kesme kuvvetine ulaştıktan sonra, etki yükü maksimum yükün 2/3'üne düşünceye kadar devam etmiştir. Yükleme başladıktan deney durduruluncaya kadar yaklaşık her $1.00 \mathrm{~mm}$ deplasman için hidrolik basınç ölçer okuması kaydedilmiştir ve yük-deplasman grafikleri çizilmiştir. Elde edilen maksimum kesme kuvveti 4'e bölünerek her bir ankrajın kesme kapasitesi, elastik ve duvarda kalıcı ezilmeler nedeniyle elasto-plastik davranışı elde edilmiştir.

B1 binası üzerinde 3 farklı çaplı $(10,12$ ve $16 \mathrm{~mm})$ ankraj çubukları için kesme deneyleri yapılmış, sonuç olarak çapın ankraj kesme kapasitesi üzerinde etkisinin az olduğu, çok yakın değerler verdiği görülmüş buna istinaden $\mathrm{B} 2$ ve B3 binalarında sadece 10 ve $16 \mathrm{~mm}$ için kesme deneyleri yapılmıştır. Ankraj donatısı başlangıçta sadece kesmeye zorlanmış olsa da duvar yüzeyinde yükün artması ile meydana gelen ezilmeler sonucunda donatıların eğilerek çekme aldığı gözlenmişse de bu çekme etkisi ile duvardan sıyrılarak çekme göçmesi görülmemiştir. Bu yüzden ankrajların kesme performansı test edilirken epoksi kullanımına ihtiyaç duyulmamıştır.

\section{BULGULAR VE TARTIŞMA}

Üç farklı binada yapılan ankraj kesme deneylerinde 3 farklı çap ve 3 farklı derinlikte ankraj donatıları kullanılmıştır. Bu deneyler sonucunda, göçmenin beklendiği üzere, ankraj donatılarının duvar içerisinde kalan kısmında parabolik bir şekil alarak, itme doğrultusunda donatı ankrajının basınç uyguladığı delik yüzeylerinde ezilmeler meydana gelmiş, donatı eğilmiş yani en çok zorlanan ankrajlar göçmek yerine, yükünü daha az zorlanan ankrajlara aktararak, yükün yeniden dağılımını mümkün kılmış ve donatıda doğrudan kesilerek ani göçme önlenmiştir (Şekil 4).
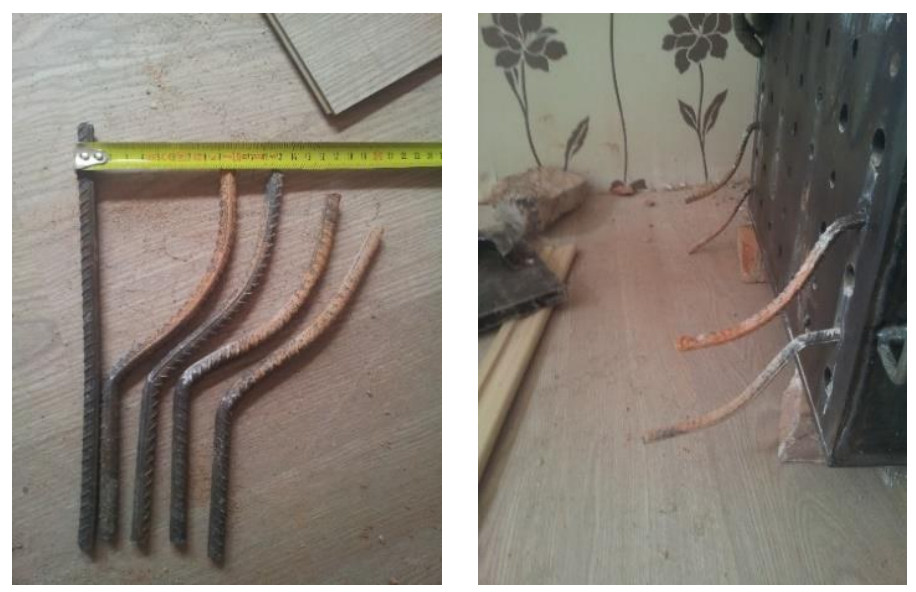

Şekil 4. Ankraj çubuklarının duvar içerisinde göçme şekli

Aynı deneyin, yığma duvara nispeten daha yüksek mukavemetli beton duvarlarda yapılması durumunda, duvar mukavemetinin artması ile ezilme daha sınırlı olacak, dolayısıyla ankraj donatılarındaki eğilmeler de azalacaktır. Böylece en çok zorlanan ankraj donatıları taşıma kapasitesinin fazlasını diğer ankrajlara aktaramadığı, yani yükün yeniden dağılımı mümkün olmayacağı için maksimum taşıma kapasitesine ulaşan ankraj donatılar, daha fazla veya doğrudan kesme ile zorlanacak ve daha erken kesme göçmeleri meydana gelecektir. Binaların inşası aşamasında kullanılan yapı 
malzemelerinin (Tuğla, sıva, örgü harcı gibi) farklı ocaklarda imal edildiği ve farklı ustalarca örülerek sıvandığı için malzemelerin mekanik özelliklerindeki bu farklılık, malzemelerin basınç mukavemeti hakkında bilgi veren tahribatsız deney yöntemlerinden biri olan N-Schmidt test çekiciyle ortaya konmuştur (Çizelge 1).

Çizelge 1.Tuğla, sıva ve örgü harcı için N-Schmidt test çekici okumalarının ortalama değerleri

\begin{tabular}{llc}
\hline Yerleşke & & N-Schmidt Test Çekici R Okumaları \\
\hline \multirow{3}{*}{ B1 } & Tuğla & $\mathbf{2 6 . 5}$ \\
& Sıva & 19.5 \\
& Örgü Harcı & 12.0 \\
B2 & Tuğla & $\mathbf{2 3 . 5}$ \\
& Sıva & 10.0 \\
& Örgü Harcı & 8.0 \\
B3 & Tuğla & $\mathbf{2 0 . 0}$ \\
& Sıva & 11.0 \\
& Örgü Harcı & 12.0 \\
\hline
\end{tabular}

Farklı üç binada kullanılan tuğla basınç dayanımlarında \%75'e varan, örgü harcı dayanımlarında \%56'ya varan ve sıva harcı dayanımlarında \%67'ye varan farklılığın olduğu ve burada tuğla hacimsel olarak en büyük örgü malzemesi olduğu kadar basınç mukavemeti olarak da en yüksek değere sahip olduğu görülmüştür.

Çizelge 2. Ø10'luk 4 ankrajda oluşan maksimum kesme kuvveti $\left(\mathrm{T}_{\mathrm{k}}\right)$ ve maksimum deplasman

\begin{tabular}{lccc} 
Yerleşke & Ankraj Donatı Derinliği (cm) & Maksimum Kesme Kuvveti $\mathbf{T}_{\mathbf{k}}(\mathbf{k N})$ & Deplasman $(\mathbf{m m})$ \\
\hline \multirow{3}{*}{ B1 } & 5 & 27.65 & 18 \\
& 10 & 49.27 & 42 \\
& 15 & 61.23 & 100 \\
B2 & 5 & 27.65 & 34 \\
& 10 & 42.73 & 52 \\
& 15 & 54.29 & 112 \\
B3 & 5 & 31.14 & 18 \\
& 10 & 49.78 & 41 \\
& 15 & 58.30 & 84 \\
\hline
\end{tabular}

Çizelge 1 ve Çizelge 2'deki veriler ışığında, duvar içerisinde en büyük hacme ve en yüksek mukavemete sahip olması nedeniyle tuğlanın, ankraj donatılarının performansı üzerinde en etkili parametre olduğu görülmektedir. Dolayısı ile Eşitlik 1'de görüldüğü üzere, en yüksek kesme mukavemeti veren $15 \mathrm{~cm}$ ve üzeri ankraj derinlikleri için, Ø10'luk bir ankraj donatısının kesme mukavemeti $\left(\mathrm{T}_{\mathrm{k}}\right)$ ile tuğla mukavemetinin göstergesi olan $\mathrm{R}$ okuma değerleri arasında, 0.9247Rkorelasyonla doğrusal bir bağıntı vardır.

$\mathrm{T}_{\mathrm{k}}=1.2828 * \mathrm{R}-17.947$ 
3 farklı bina üzerinde, $\varnothing 10^{\prime}$ luk ankraj donatısının farklı ankraj derinliklerindeki yapılan kesme deneyi sonuçları Çizelge 2'de ve grafiksel olarak Şekil 5, 6 ve 7.'de verilmiştir.

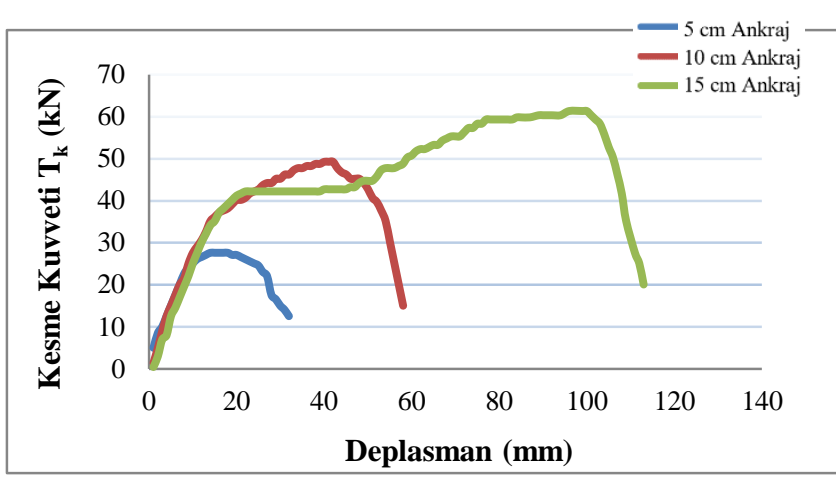

Şekil 5. B1 için Ø10’luk ankraj donatısı için $T_{k}$ ve deplasman grafiği

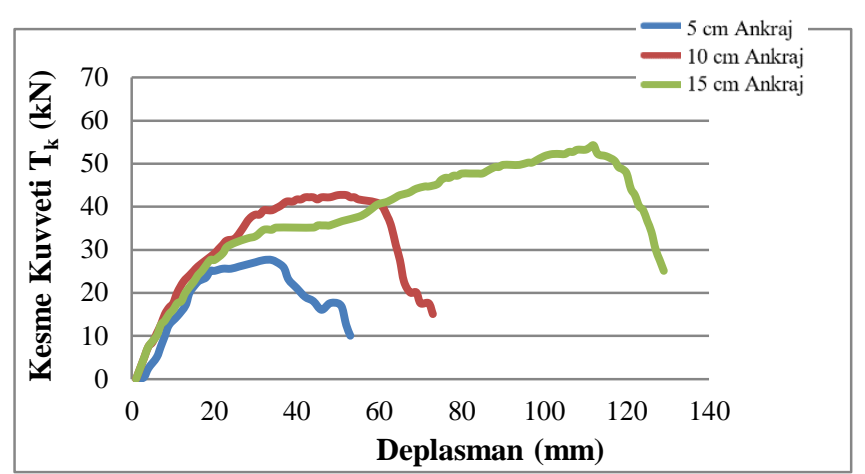

Şekil 6.B2 için Ø10’luk ankraj donatısı için $T_{k}$ ve deplasman grafiği

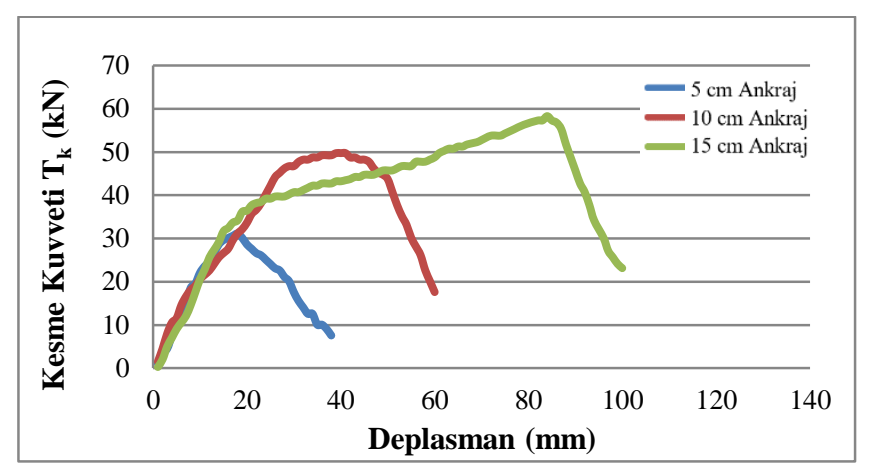

Şekil 7. B3 için Ø10’luk ankraj donatısı için $T_{k}$ ve deplasman grafiği

Çizelge 3. Ø12'lik ankrajlarda oluşan maksimum kesme kuvveti $\left(\mathrm{T}_{\mathrm{k}}\right)$ ve maksimum deplasman

\begin{tabular}{cccc}
\hline Yerleşke & Ankraj Donatı Derinliği (cm) & Maksimum Kesme Kuvveti $\mathbf{T}_{\mathbf{k}}(\mathbf{k N})$ & Deplasman $(\mathbf{m m})$ \\
\hline \multirow{2}{*}{ B1 } & 5 & 31.16 & 19 \\
& 10 & 51.28 & 56 \\
& 15 & 64.32 & 86 \\
\hline
\end{tabular}

Çizelge 4. Ø16'lık ankrajlarda oluşan maksimum kesme kuvveti $\left(\mathrm{T}_{\mathrm{k}}\right)$ ve maksimum deplasman

\begin{tabular}{lccc}
\hline Yerleşke & Ankraj Donatı Derinliği $(\mathbf{c m})$ & Maksimum Kesme Kuvveti $\mathbf{T}_{\mathbf{k}}(\mathbf{k N})$ & Deplasman $(\mathbf{m m})$ \\
\hline \multirow{3}{*}{ B1 } & 5 & 34.64 & 11 \\
& 10 & 54.81 & 48 \\
& 15 & 68.71 & 95 \\
B2 & 5 & 27.14 & 16 \\
& 10 & 45.24 & 50 \\
& 15 & 56.30 & 85 \\
B3 & 5 & 32.67 & 18 \\
& 10 & 55.29 & 44 \\
& 15 & 63.84 & 77 \\
\hline
\end{tabular}

Şekil 5, 6 ve 7'de görüldüğü üzere, ankraj derinliğinin artması ile ankraj kesme performansının da azalan bir eğilimle parabolik olarak arttığı ve deplasman miktarı ile birlikte potansiyel enerji yutma kapasitesinin de arttığı görülmektedir. Gömme derinliği fazla olan ankrajların maksimum kesme 
kuvvetine daha yüksek deplasmanlarda ulaştığı ancak maksimum yüke ulaştıktan sonra hılı bir yük kaybı ile ani denebilecek göçmenin gerçekleştiği görülmektedir. B1'de farklı ankraj derinliklerindeki Ø12'lik ankraj donatısı için yapılan kesme deneyi verileri Çizelge 3 ve Şekil 8'de verilmiştir.

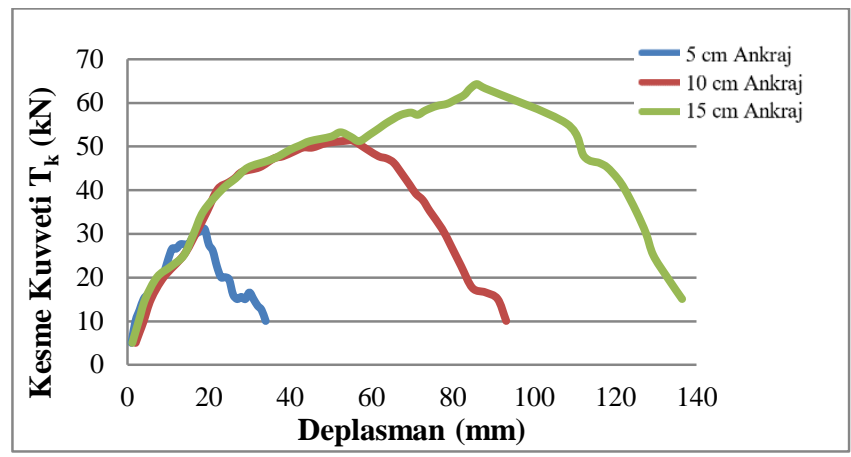

Şekil 8. B1 için Ø12'lik ankraj donatısı için $T_{k}$ ve deplasman grafiği

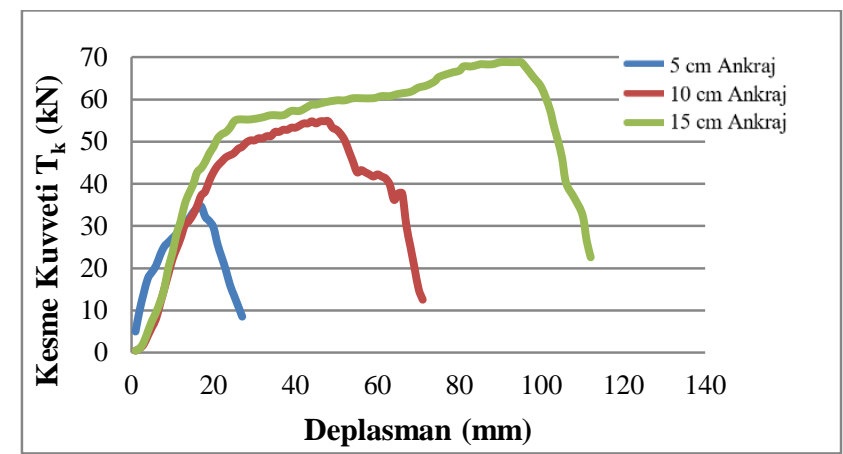

Şekil 9. B1 için Ø16’lık ankraj donatısı için $T_{k}$ ve deplasman grafiği

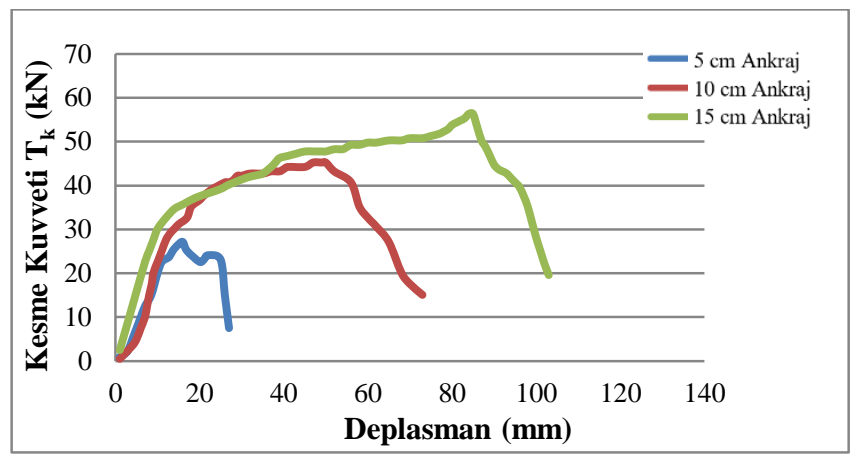

Şekil 10. B2 için Ø16'lık ankraj donatısı için $T_{k}$ ve deplasman grafiği

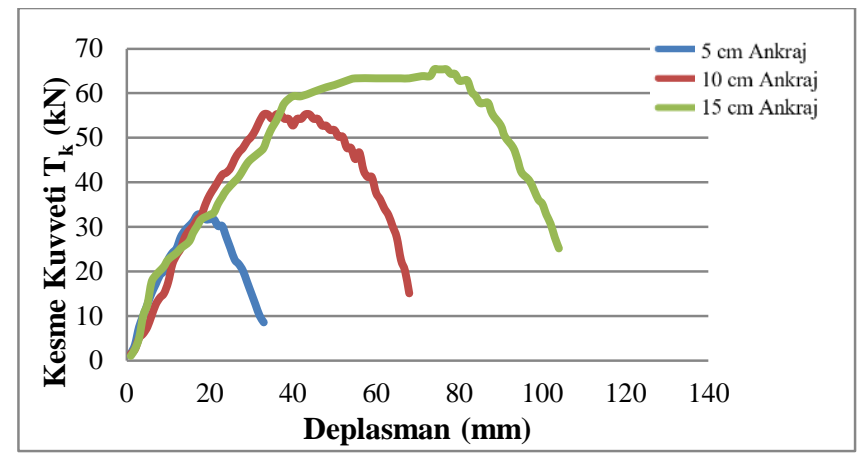

Şekil 11. B3 için Ø16'lık ankraj donatısı için $T_{k}$ ve deplasman grafiği

3 farklı binada farklı ankraj derinliklerindeki Ø16'lık ankraj donatısı için yapılan kesme deneyi sonuçlarına ilişkin kesme ve deplasman değerleri Çizelge 4'te ve grafiksel değerlendirmesi Şekil 9, 10 ve 11 'de verilmiştir. Binaların duvar malzemelerinin kalitesine bağlı olarak, farklı gömme derinlikleri için maksimum kesme kuvvetleri değişirken maksimum deplasmanlar birbirlerine çok yakın gerçekleşmiştir.

Şekil 5-11'de görüldüğü üzere Ø16'lık ankraj donatısı deneyinde ankraj donatı çapının artmasıyla birlikte Ø10'luk ve Ø12'lik çaplara göre maksimum taşıma kapasitesinin çap artışına oranla daha az artmıştır. Ancak maksimum yüke karşılık gelen deplasman miktarlarının azaldığı görülmüştür. 
Maksimum kesme kuvvetleri ve buna karşılık deplasman miktarlarının, ankraj çapı ve derinliğine bağlı olarak değiştiği görülmüştür.

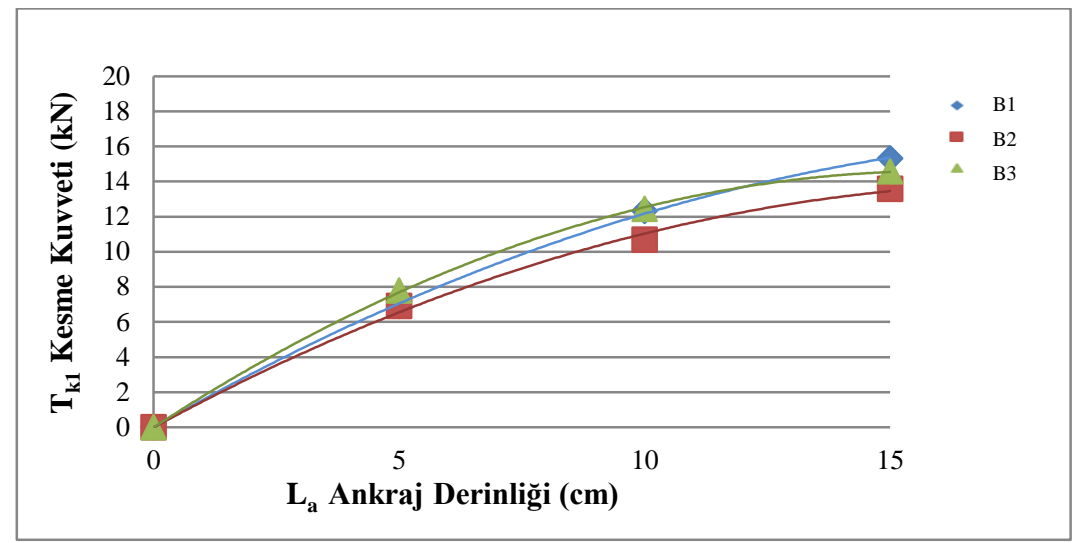

Şekil 12. B1, B2, B3 için Ø10’luk ankrajlarda ankraj derinliği ile kesme kuvveti bağıntısı

B1 (GMK Bulvarı No:125)

B2 (Bişkek Cad. No:44)

B3 (Bahriye Üçok Cad. No:11)

$$
\begin{array}{ll}
\left(\mathrm{R}_{\text {tuğla }}=26.5\right) & \mathrm{T}_{\mathrm{k} 1}=-0.0387 \mathrm{~L}_{\mathrm{a}}^{2}+1.6047 \mathrm{~L}_{\mathrm{a}} \\
\left(\mathrm{R}_{\text {tuğla }}=23.5\right) & \mathrm{T}_{\mathrm{k} 1}=-0.0414 \mathrm{~L}_{\mathrm{a}}^{2}+1.5179 \mathrm{~L}_{\mathrm{a}} \\
\left(\mathrm{R}_{\text {tuğla }}=20.0\right) & \mathrm{T}_{\mathrm{k} 1}=-0.0569 \mathrm{~L}_{\mathrm{a}}^{2}+1.8225 \mathrm{~L}_{\mathrm{a}}
\end{array}
$$

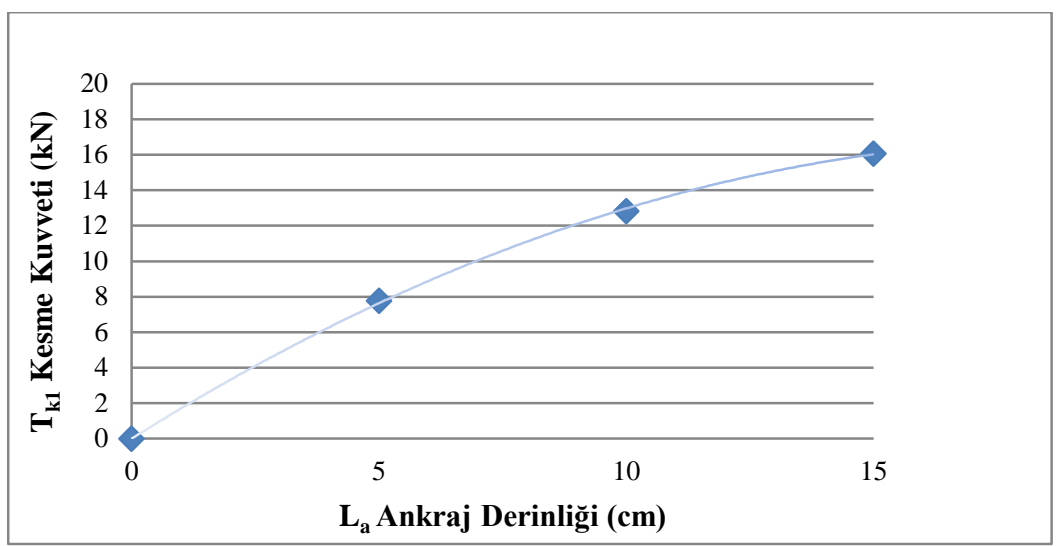

Şekil 13. B1 için Ø12’lik ankrajlarda ankraj derinliği ile kesme kuvveti bağıntısı

B1 (GMK Bulvarı No:125) $\quad\left(\mathrm{R}_{\text {tuğla }}=26.5\right) \quad \mathrm{T}_{\mathrm{k} 1}=-0.0458 \mathrm{~L}_{\mathrm{a}}^{2}+1.756 \mathrm{~L}_{\mathrm{a}}$

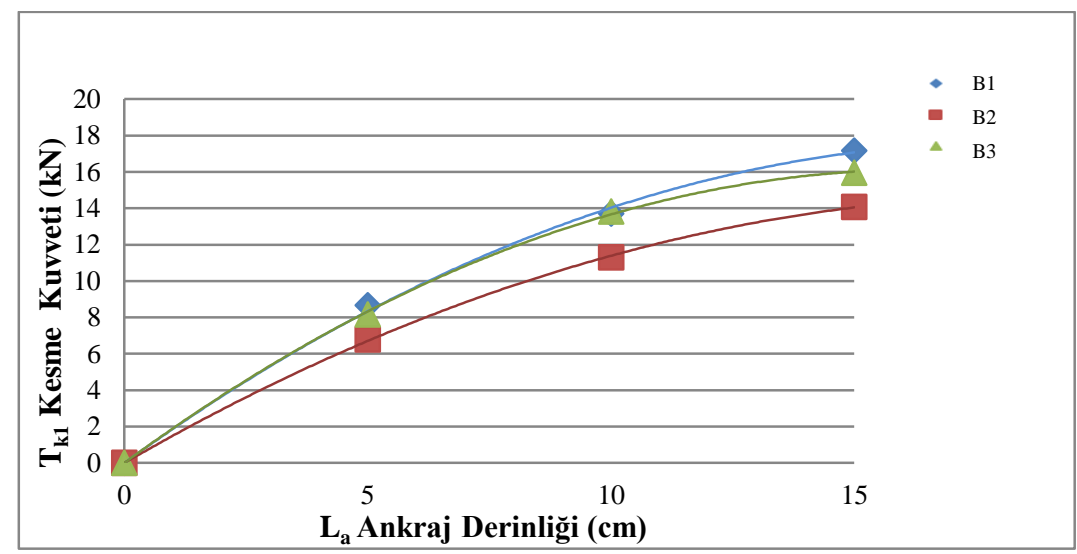

Şekil 14. B1, B2, B3 için Ø16'lık ankrajlarda ankraj derinliği ile kesme kuvveti bağıntısı 


$\begin{array}{lll}\text { B1 (GMK Bulvarı No:125) } & \left(\mathrm{R}_{\text {tuğla }}=26.5\right) & \mathrm{T}_{\mathrm{k} 1}=-0.0529 \mathrm{~L}_{\mathrm{a}}^{2}+1.9319 \mathrm{~L}_{\mathrm{a}} \\ \text { B2 (Bişkek Cad. No:44) } & \left(\mathrm{R}_{\text {tuğla }}=23.5\right) & \mathrm{T}_{\mathrm{k} 1}=-0.0405 \mathrm{~L}_{\mathrm{a}}^{2}+1.5437 \mathrm{~L}_{\mathrm{a}} \\ \text { B3 (Bahriye Üçok Cad. No:11) } & \left(\mathrm{R}_{\text {tuğla }}=20.0\right) & \mathrm{T}_{\mathrm{k} 1}=-0.0598 \mathrm{~L}_{\mathrm{a}}^{2}+1.9643 \mathrm{~L}_{\mathrm{a}}\end{array}$

Söz konusu üç binaya ait Ø10, Ø12 ve Ø16’lık ankaraj donatılarının kesme kuvveti $\mathrm{T}_{\mathrm{k} 1}$ ile ankraj derinliği $\mathrm{L}_{\mathrm{a}}$ arasında $\mathrm{R}^{2}=0.99$ regrasyonla çok uyumlu denklemler elde edilmiştir. Bu denklemler arasındaki farklılığın, binaların duvar örgü malzemelerinin mekanik özelliklerine, özellikle de tuğlanın mukavemetinin göstergesi olan çekiç okumalarına ( $\mathrm{R}_{\text {tuğla }}$ ) bağlı olduğu görülmektedir (Şekil 12, 13, 14). Ø10’luk, Ø12'lik ve Ø16'lık ankraj çapları için $5 \mathrm{~cm}, 10 \mathrm{~cm}$ ve $15 \mathrm{~cm}$ gömme derinliğine bağlı olarak elde edilen ankraj kesme kuvvetlerinin, azalan bir eğilim çizgisiyle parabolik olarak arttığ görülmüştür. Bir adet Ø10'luk ankraj için ankraj derinliği $5 \mathrm{~cm}$ 'den 3 katı olan $15 \mathrm{~cm}$ 'ye çıktığında binaların tuğla, sıva ve örgü harcı dayanımlarına bağlı olarak bir adet ankrajın kesme kuvvetinin $\left(T_{k 1}\right)$ her üç bina için ortalama iki katı (\%100) arttığı görülmüştür (Şekil 12, 13,14).

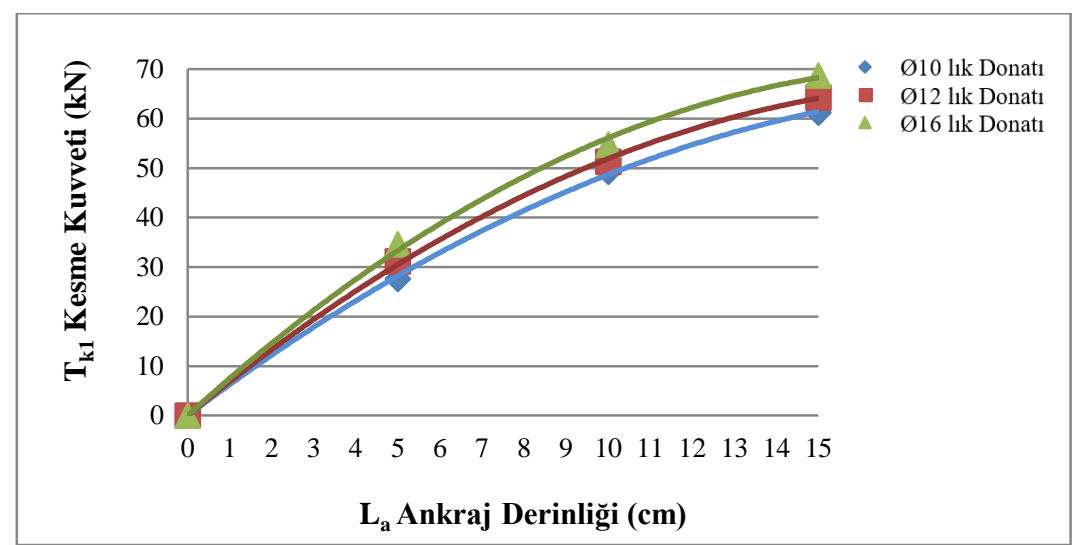

Şekil 15. B1 için Ø10’luk, Ø12'lik ve Ø16’lık Ankrajlarda $T_{k} K^{\prime}$ esmeKuvveti (kN) ile L Ankraj Derinliği (mm) Grafiği

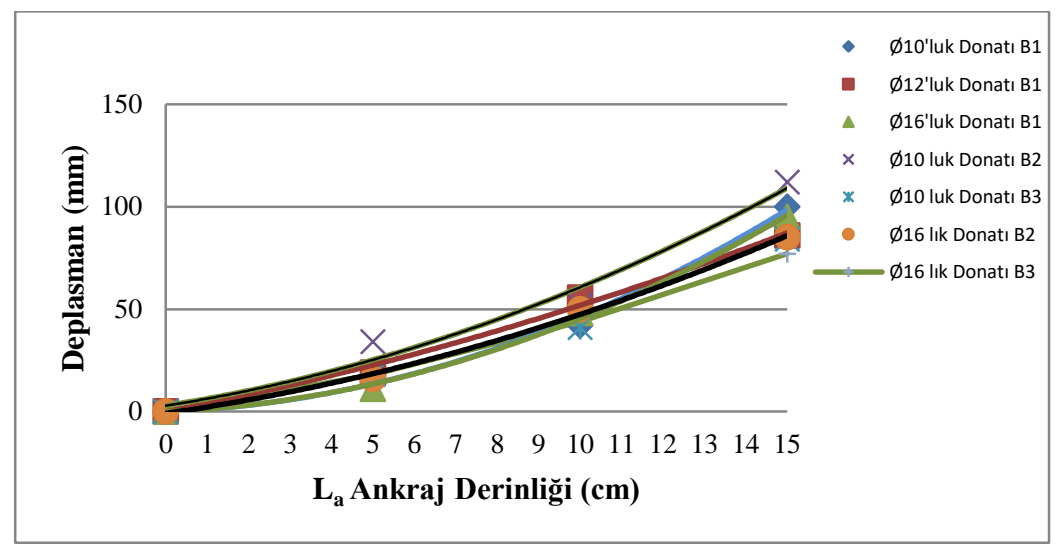

Şekil 16. Ø10’luk, Ø12’lik ve Ø16’lık Ankrajlar için Deplasman-Ankraj Derinliği Grafiği

Şekil 14'de B1 için ankaraj çapının ankraj kesme performansına etkisine bakılmış ve Ø10'luk, Ø12'lik ve Ø16'lık ankrajların derinliğinin artması ile uyumlu bir şekilde kesme performansının da parabolik olarak arttığı görülmüştür. Ankraj derinliği $5 \mathrm{~cm}$ için kesme kapasitesi $30 \mathrm{kN}$, derinliğinin 5 cm'den 10 cm'ye çıkması ile kesme kapasitesindeki artışın yaklaşık 20 kN, 10 cm'den 15 cm'ye çıkması ile de bu artışın yaklaşık $10 \mathrm{kN}$ kadar arttığı görülmektedir. Artan ankraj derinliği için kesme performansının aynı oranda değil azalan bir eğilimle arttığı görülmektedir. Dolayısıyla ankraj derinliğini 15 cm'den 20 cm'ye çıkmasıyla bu artışın yaklaşık $5 \mathrm{kN}$ olacağı düşünülürse, ankraj derinliğinin 20 
cm'den daha fazla yapılmasının ekonomik maliyeti artırmanın dışında pek katkısı olmayacağı kanaatine varılmıştır. Aynı gömme derinliği için 3 farklı ankraj çapının kesme değerlerinin birbirine yakın olduğu, görülmüştür. Ankraj çapındaki \%50 artışa karşılık kesme performansının yaklaşık \%10 arttığ görülmektedir. Dolayısıyla Ø10’luk ankrajın diğerlerine oranla tercih edilmesinin daha ekonomik ve kolay olacağı kanaatine varılmıştır (Şekil 15).

Ankraj derinliğinin artması ile ankraj kesme kapasitesindeki artış trendi düşerken, deplasmanındaki parabolik artışın daha yüksek olduğu, dolayısıyla daha elastik ve sünek davrandığı görülmektedir (Şekil 16).

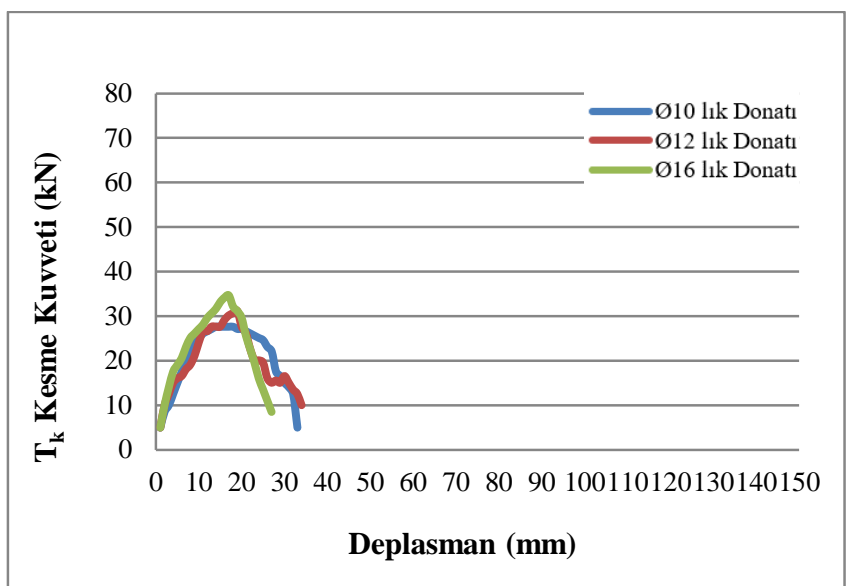

Şekil 17. $5 \mathrm{~cm}$ ankraj derinliği için farklı ankraj çaplarının kesme yükü ve deplasman grafiği

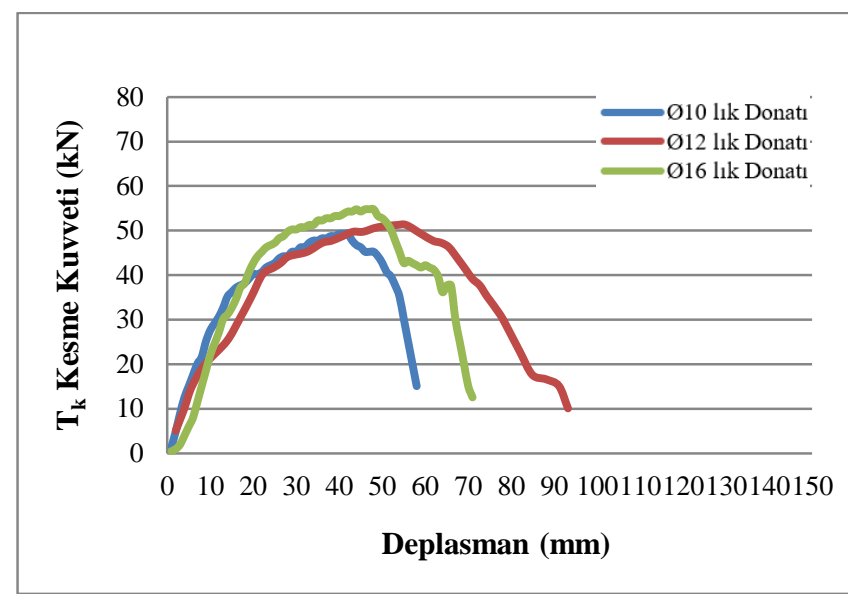

Şekil 18. $10 \mathrm{~cm}$ ankraj derinliği için farklı ankraj çaplarının kesme yükü ve deplasman grafiği

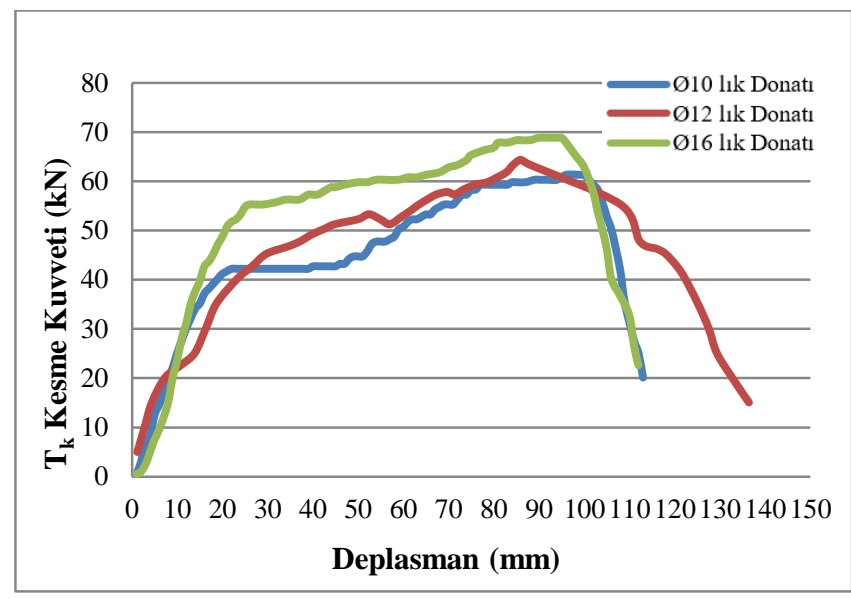

Şekil 19. 15 cm ankraj derinliği için farklı ankraj çaplarının kesme yükü ve deplasman grafiği

Şekil 17-18-19'da görüldüğü gibi Ø10'luk çaptan Ø16'lık çapa geçişte deplasman artışının daha düşük ve ankrajın daha rijit olduğu görülmüştür. Yığma yapılarda kesme kuvvetlerinin hesaplandığ duvar yüzeyleri betonarme gibi homojen ve güçlü bir yapıya sahip değildir. Bu nedenle yığma yapılarda ankraj çapı arttıkça uygulanan $T_{k}$ kuvvetiyle birlikte duvar yüzeyinde görülen deformasyon miktarı da artmaktadır. Bu durumda ankraj çapı arttıkça deplasman miktarında çap artışıyla azalış görülmüştür.

B2' de Ø10'luk ankrajın $15 \mathrm{~cm}$ gömme derinliği için deplasman miktarı $112 \mathrm{~mm}$ olmasına rağmen, Ø16’lık ankrajın $15 \mathrm{~cm}$ gömme derinliğinde deplasman miktarı $85 \mathrm{~mm}$ olarak ölçülmüştür. Benzer durumla B3'de Ø10'luk ankrajın $15 \mathrm{~cm}$ gömme derinliğinde deplasman miktarı $84 \mathrm{~mm}$ olmasına rağmen Ø16'lık ankraj $15 \mathrm{~cm}$ gömme derinliğinde deplasman miktarı $77 \mathrm{~mm}$ ve B1'de ise Ø10' luk ankrajın 15 
cm gömme derinliğinde deplasman miktarı $100 \mathrm{~mm}$, Ø16 çapında $15 \mathrm{~cm}$ gömme derinliğinde deplasman miktarı 95 mm olarak ölçülmüştür.

Ø10, Ø12 ve Ø16 çaplarındaki ankraj donatıları üzerinde yapılan deneylerde, ankraj çaplarının değişmesinin, ankraj donatısının maksimum kesme kuvveti ve enerji yutma kapasitesi bakımından etkisinin ihmal edilecek derecede az olduğu görülmektedir. Ankraj donatı çapı arttıkça, ne kesme yükünde beklenen düzeyde artış, ne de ankrajlardaki artan eğilme rijitliği nedeniyle beklenen ani kesme göçmeleri gözlenmemiş hem maksimum kesme kuvvetinde hem de göçme deplasmanlarındaki artış ihmal edilecek kadar az olmuştur.

Ancak, 5 cm'den 10 cm'ye çıkması ile yani 2 katına çıkması ile daha süneklik davranarak, şekil değiştirme kapasitesine paralele olarak, enerji yutma kapasitesinin de yaklaşık 4 katı arttığı, 3 katına çıkması ile de enerji yutma kapasitesinin yaklaşık 8 katı arttığı gözlenmiştir. Sonuç olarak, ankraj donatısının gömme derinliğinin artması ile hem kesme yükü kapasitelerinin hem de göçme şekil değiştirme ve enerji yutma kapasitelerinin arttığı gözlenmiştir. Ankraj kesme performansını birinci dereceden etkileyen parametrenin duvar tuğlası dayanımının, örgü harcı dayanımının ve ankraj derinliğinin olduğu da görülmüştür. Ancak bu artışın eğilim çizgisinin gömme derinliği ile aynı oranda yani lineer olarak artmadığı, parabolik olarak azaldığı da göz önüne alındığında, ankraj derinliğinin 15 cm'den sonra çok azalacağı, 20 cm'den sonra da ihmal edilecek kadar az olacağı görülmüştür.

Sonuç olarak, küçük çaplı ankrajların uygulama kolaylığı ve maliyetinin de düşük olacağı göz önüne alındığında, duvar güçlendirmelerinde küçük çaplı ankrajlar tercih edilmelidir. Ayrıca duvar mukavemetinin artması ile bu ankraj derinliğinin kesme performansı üzerindeki etkisi azalacağından, etkili gömme derinliğinin de daha az olacağı anlaşılmaktadır.

\section{SONUÇ}

Yığma veya betonarme binalar, ek bir çelik veya betonarme panel ile güçlendirilirken, mevcut elemanların yüklerini güçlendirme elemanlarına tam aktarabilmesi güçlü ara bağlantı elemanları ile mümkün olacaktır. Ara bağlantı elemanlarının hangi çap ve derinlikte, kaç adet ve ne kadar aralıklarla duvara ankre edileceğini belirlemek için, güçlendirme analizleri öncesinde kesme performansının yerinde tespit edilmesi, analizlerin güvenilirliği bakımından çok önemlidir.

$\mathrm{Bu}$ çalışma ile üç farklı yı̆̆ma binanın duvarlarında, özel tasarlanmış kesme levhası kullanılarak, farklı çaplarda ankraj donatıları duvarlara yine farklı derinliklerde ankrajlanarak, kesme performanlarını belirlemek amacıyla kesme deneyleri yapılmıştır. Elde edilen deney sonuçları değerlendirildiğinde;

- Farklı üç binada kullanılan tuğla basınç dayanımlarında \%33'e varan, örgü harcı dayanımlarında \%50'ye varan ve sıva harcı dayanımlarında \%95'e varan farklılığın olduğu görülmüş ve burada tuğla hacimsel olarak en büyük örgü malzemesi olduğu kadar basınç mukavemeti olarak da en yüksek değere sahip olduğu, dolayısı ile yığma bina performans ve güçlendirmelerinde analizlerinde, binaların sadece tuğla cinsine ve boşluk oranına bağlı olarak, mekanik özelliklerinin sabit değerlerle tanımlanamayacağı görülmüştür.

- $\mathrm{Bu}$ deneyler sonucunda, binanın ankraj kesme kapasitesinin en kolay ve en az maliyetle elde edilmesi ve en iyi performansı vermesi bakımından, Ø10'luk bir ankrajın kesme mukavemeti $\left(\mathrm{T}_{\mathrm{k}}\right)$ ile tuğla duvarın çekiç okuma $\mathrm{R}$ değerleri arasında, $\mathrm{R}^{2}=0.9247$ regrasyonla doğrusal bir bağıntı elde edilmiştir.

- $\quad$ Ø16'lık ankraj donatısı deneyinde ankraj donatı çapının artmasıyla birlikte Ø10'luk ve Ø12'lik çaplara göre maksimum taşıma kapasitesinin çap artışına oranla az arttığı ancak maksimum yüke karşılık gelen deplasman miktarlarının azaldığı, dolayısı ile maksimum kesme kuvvetlerinin ankraj çapından ziyade ankraj derinliğine bağlı olarak değiştiği görülmüştür. 
- $\quad \mathrm{Bu}$ deneyler sonucunda, benzer örgü tuğlalı binaların performans ve güçlendirme analizlerinde kullanılabilecek Ø10, Ø12 ve Ø16'lık ankaraj donatılarının kesme kuvveti $\mathrm{T}_{\mathrm{k} 1}$ ile ankraj derinliği $\mathrm{L}_{\mathrm{a}}$ arasında $\mathrm{R}^{2}=0.99$ regrasyonla çok uyumlu denklemler elde edilmiştir. Bu denklemler arasındaki farklılığın, binaların duvar örgü malzemelerinin mekanik özelliklerine, özellikle de tuğlanın mukavemetinin göstergesi olan çekiç okumalarına ( $\left.\mathrm{R}_{\text {tuğla }}\right)$ bağlı olduğu görülmüştür.

- Ankraj kesme performansında, birinci dereceden ankraj derinliğinin etkili olduğu, bir adet Ø10'luk ankraj için ankraj derinliği 5 cm'den 3 katı olan 15 cm'ye çıktığında binaların tuğla, sıva ve örgü harcı dayanımlarına bağlı olarak bir adet ankrajın kesme kuvvetinin $\left(\mathrm{T}_{\mathrm{k} 1}\right)$ her üç bina için ortalama iki katı arttığı görülmüştür. Dolayısıyla ankraj derinliğini 15 cm'den 20 cm'ye çıkmasıyla bu artışın yaklaşık $5 \mathrm{kN}$ olacağı düşünülürse, ankraj derinliğinin $20 \mathrm{~cm}$ 'den daha fazla yapılmasının ekonomik maliyeti artırmanın dışında pek katkısı olmayacağı kanaatine varılmıştır.

- Aynı gömme derinliği için 3 farklı ankraj çapının kesme değerlerinin birbirine yakın olduğu, görülmüştür. \%50 ankraj çapındaki artışa karşılık kesme performansının yaklaşık \%10 arttığ1, dolayısıyla Ø10'luk ankrajın diğerlerine oranla tercih edilmesinin daha ekonomik ve kolay olacağı kanaatine varılmıştır.

- Ankraj derinliğinin 5 cm'den 10 cm'ye çıkması ile yani 2 katına çıkması ile daha sünek davranarak, şekil değiştirme kapasitesine paralele olarak, enerji yutma kapasitesinin de yaklaşık 4 katı arttığı, 3 katına çıkması ile de enerji yutma kapasitesinin yaklaşık 8 katı arttığı, ankraj kesme kapasitesindeki artış trendi düşerken, deplasmanındaki parabolik artışın daha yüksek olduğu, hem kesme yükü kapasitelerinin hem de göçme şekil değiştirme ve enerji yutma kapasitelerinin arttığı, dolayısıyla daha elastik ve sünek davrandığı görülmüştür.

- Ankraj donatı çapı arttıkça, ankraj donatısının maksimum enerji yutma kapasitesi bakımından etkisinin ihmal edilecek derecede az olduğu, ne kesme yükünde beklenen düzeyde artış, ne de ankrajlardaki artan eğilme rijitliği nedeniyle beklenen ani kesme göçmeleri gözlenmemiş, hem maksimum kesme kuvvetinde hem de göçme deplasmanlarındaki artış ihmal edilecek kadar az olmuştur

- Bu çalışmalar ile, küçük çaplı ankrajların uygulama kolaylığı ve maliyetininde düşük olacağı göz önüne alındığında, duvar güçlendirmelerinde $Ø 8$ ve $Ø 10$ gibi küçük çaplı ankraj donatılarının tercih edilmesi gerektiği, ayrıca duvar mukavemetinin artması ile bu ankraj derinliğinin kesme performansı üzerindeki etkisi azalacağından, etkili gömme derinliğinin de sıva kalınlığı hariç $20 \mathrm{~cm}$ ile sınırlı tutulması gerektiği sonucuna varılmıştır.

Bu çalışmalara ek olarak, deneylerde kullanmış olduğumuz özel tasarlanmış, pratik ve kullanışlı çelik levhalı deney düzeneğiyle;

- Daha farklı binalar üzerinde Ø8 ve Ø10'luk ankaraj donatıları kullanılarak, daha büyük ankraj derinlikleri için bu kesme deneyleri yapılarak, gömme derinliğine ve ankraj donatısının kesme performansının tuğla mukavemetinin göstergesi olan N-Schmidt okumalarına bağlı daha sağlıklı bir denklem elde edilebileceği,

- Farklı duvar örgü tuğlaları için benzer deneyler yapılarak benzer denklemler ortaya konabileceği,

- Duvar mukavemetinin artması ile bu ankraj derinliğinin kesme performansı üzerindeki etkisi azalacağı, etkili gömme derinliğinin de daha az olacağından, mukavemeti daha yüksek beton perde elemanlar için benzer deneyler yapılarak benzer denklemler ortaya konabileceği önerimizdir.

\section{Çıkar Çatışması}

Makale yazarları aralarında herhangi bir çıkar çatışması olmadığını beyan ederler. 


\section{Yazar Katkısı}

Yazarlar makaleye eşit oranda katkı sağlamış olduklarını beyan eder.

\section{KAYNAKLAR}

Akgül M, Doğan O, 2019. Yığma Yapılarda Güçlendirme Yöntemleri ve TBDY-2018'de Yığma Yapılar. Munzur 1. Uluslararası Uygulamalı Bilimler Kongresi, 24-26 Mayıs 2019, Tunceli, Türkiye.

Akgül M, Doğan O, 2020. 4 Nisan 2019 Elâzı ğ-Sivrice Depreminin Yığma Yapılara Etkisinin Değerlendirilmesi. International Journal of Engineering Research and Development, 12 (1): 265-277. doi.org/10.29137/umagd.621701

Akgül M, Doğan O, 2020. Altındağ/Ankara Özelinde Tipik Yığma Binaların Deprem Risklerinin 2018 Türkiye Bina Deprem Yönetmeliğine Göre İncelenmesi. Engineering Sciences (NWSAENS), 15(1):1-14. doi: 10.12739/NWSA.2020.15.1.1A0446

Bayülke N, 1992, Yığma Yapılar (Genişletilmiş 2. Baskı), Bayındırlık ve İskân Bakanlığı Deprem Araştırma Dairesi Başkanlığı, Ankara.

Çalışkan Ö, 2010. Mevcut Betonarme Binaların Dış Perde Duvar ile Güçlendirilmesinde Ankraj Uygulamalarının Deneysel Olarak Araştırılması, Eskişehir Osmangazi Üniversitesi Fen Bilimleri Enstitüsü, Doktora Tezi, (Basılmış)

Çalışkan Ö, Yılmaz S, Kaplan H, 2011. Güçlendirme Ankrajlarının Kesme Dayanımının ACI318 ve TS500’e Göre Belirlenmesi. Kahramanmaraş Sütçü İmam Üniversitesi Mühendislik Bilimleri Dergisi, 14(3), 19-27.

Çelik F, 2018. Mevcut Yığma Binalarda Depremsel Güçlendirme Ankrajlarının Çap ve Ankraj Derinliğine Bağlı Çekme ve Kesme Performanslarının Deneysel Olarak İncelenmesi, Kırıkkale Üniversitesi Fen Bilimleri Enstitüsü, Yüksek Lisans Tezi (Basılmış)

Doğan O, Odacioğlu O, 2019. An Experimental Study To Determine Sliding Shear Strength And Internal Friction Coefficient Of ClayBrick Wall In A Masonry Building. International Journal of Engineering Researchand Development, 11 (2): 670-676. doi.org/10.29137/umagd.545396

Doğan O, Çelik F, Erkmen K.C, Bande B, Akgül M, 2020. Mevcut Yığma Duvarlara Yapılan Kimyasal Ankrajların Çekme Performansının Tam ve Kısmi Sıyrılmalı Yöntemlerle Deneysel Olarak Belirlenmesi. Constructıon Materıals Engıneerıng and Architecture Congress, 12-14 June, Ankara, Türkiye.

Odacıoğlu O.G, 2018. Yığma Binalarda Yatay Yük Hesabına Esas Kesme Performansının Deneysel Olarak Belirlenmesi, Kırıkkale Üniversitesi Fen Bilimleri Enstitüsü, Yüksek Lisans Tezi (Basılmış)

Öztürk B, 1997. Analysis and Design of Prestressed Concrete Sheet Pile Walls, Orta Doğu Teknik Üniversitesi Fen Bilimleri Enstitüsü, Yüksek Lisans Tezi (Basılmış)

Silveri F, Riva P, Profeta G, Poverello E, Algeri C, 2016. Experimental Study on Injected Anchors forthe Seismic Retrofit of Historical Masonry Buildings. International Journal of Architectural Heritage, 10(2-3): 182-203.

TS EN 12504-2. 2014. Yapılarda beton deneyleri - Bölüm 2: Tahribatsız muayene - Geri sıçrama sayısının belirlenmesi. Ankara : Türk Standatları Enstitüsü. 